\title{
ENGEVISTA
}

Página da revista: http://www.uff.br/engevista/seer/

\section{Drying of rye (Lolium miltiflorum l.) in fixed bed with parallel air flow}

\author{
Akel Ferreira Kanaan ${ }^{1}$ \\ Janice Botelho Souza Hamm ${ }^{2}$ \\ Camila Gomes Flores ${ }^{3}$ \\ João Carlos Pinto Oliveira ${ }^{4}$ \\ André Ricardo Felkl de Almeida ${ }^{5}$
}

\begin{abstract}
This work aimed to study the drying of ryegrass seeds (Lolium multiflorum L.) in fixed bed dryer with parallel air flow. The study consisted of physical and physiological characterization of seeds, seed rewetting, study the desorption isotherms of rewetted seeds and the drying process of the rewetted seeds under the following conditions: temperature from 40 to $60^{\circ} \mathrm{C}$, air velocity 1.0 and $2.0 \mathrm{~m} / \mathrm{s}$ and the height of the tray 0.005 and 0.01 m. The experimental data showed that the drying conditions applied to the seeds can significantly influence the moisture content and the physiological quality of the final product.
\end{abstract}

Keywords: Drying; ryegrass; forage; isotherm; desorption.

\footnotetext{
${ }^{1}$ Unipampa - Universidade Federal do Pampa

${ }^{2}$ Unipampa - Universidade Federal do Pampa

${ }^{3}$ Unipampa - Universidade Federal do Pampa

${ }^{4}$ Empresa Brasileira de Pesquisa Agropecuária (Pecuária Sul)

${ }^{5}$ Unipampa - Universidade Federal do Pampa
} 


\section{Introduction}

According to Mota et al., (1981), in Rio Grande do Sul, approximately $61 \%$ of the vegetation cover consists of native grasslands which have vegetative growth in the warm seasons. However, in the cold seasons a reduction in production occurs, so it becomes necessary to do a fodder implementation (De Oliveira and Barreto, 1976). An alternative to reach this demand is the ryegrass (Lolium multiflorum L.), a forage that shows and good adaptability to the climatic conditions of the Rio Grande do Sul state. Despite of this, ryegrass (Lolium multiflorum L.) presents a limiting factor for the implementation of pastures due to the low rate of seed germination (range 60-70\%). This occurs due to low seed quality, a fact that is tied to an improvement process which limiting step is the drying process.

According to Strumillo and Kudra (1986) the drying is defined as the removal of liquid from a solid by evaporation (Singh et al., 2008). In drying processes, the wet material is placed in contact with the unsaturated air and as a result has a simultaneous heat and mass transfer with decreased moisture content of the material and air humidification (Mujumdar, 1987; Atefi et al., 2004; Corrêa et al., 2006; Martinazzo et al., 2007; Haghi and Amanifard, 2008). Thus, two stages define the total drying process, heating the material and evaporation of moisture to reach the equilibrium moisture content (Keey, 1992).

In accordance with Ferrari Filho (2011), the main drying advantages are the possibility of early harvest reducing losses in the field caused by undesirable climatic conditions and/or attacked by rodents, insects, birds and microorganisms. The early harvest also enables producers to obtain prices for products when marketing occur in off-season times. Also allows the formation of buffer market stocks and offer high-quality products, in the case of grains by organoleptic and nutritional characteristics, and in the case of seeds, the high percentage of germination and vigor.

For Goneli (2008) the useful life of many products can be determined by drying and storage process. In these processes, the knowledge of the relationship between the moisture of the material and the relative humidity is essential (Samapundo et al., 2007; Celma et al., 2009).

Fixed bed drying of moist particles is a technique widely applied in agricultural and chemical engineering in the form of thick-layer bed drying or thin-layer drying. Products such as grains, seeds and coal are usually dried this way (Faria and Rocha, 2000).

Several authors, such as Samaniego-Esguerra et al., (1991), Morey et al., (1995), Chen and Jayas (1998), Andrade (2003), argue that the values of equilibrium moisture content of organic products depend on the species, the variety, the initial moisture content and especially the temperature and humidity of the environment in which they find themselves. To Figueirêdo and Queiroz (2007), the study of water activity can be done by isotherms evaluations.

In line with Park et al., (2008), a sorption isotherm can be described as adsorption or desorption type. When a drier material is placed in various atmospheres, increasing the relative humidity and measuring the weight gain due to moisture gain, it is considered as an adsorption 
isotherm. The desorption isotherm is when the initially wet material is placed under the same environmental conditions used in adsorption with measurement of weight loss due to water outlet. The desorption isotherm has higher moisture values of the equilibrium adsorption isotherm under a certain amount of water activity.

Despite of the ryegrass be a forage widely available in the market, the literature does not provide technical information about your kinetic drying, water activity and desorption isotherms. Studies on these parameters are required to optimize the processing of this material in order to enable the achievement of a better quality product that meets consumer demands.

Thus, this study aimed to study the drying of ryegrass seeds (Lolium multiflorum L.) in fixed bed dryer with parallel air flow seeking to analyze the physiological quality of the final product. Physical and physiological characterization of the seeds, analysis of the rewetting seeds process, study the desorption isotherms of rewetted seeds, evaluate the effects of temperature, air velocity and height of the tray on the kinetics drying towards to physiological quality of the final product are the specific goals of the research.

\section{Methods and materials}

\subsection{Material}

Seeds of ryegrass (Lolium multiflorum L.), obtained in the city of Bagé/RS were used to carry out this work. The seeds were acquired at once in order to have enough material belonging to the same lot till the end of this research to maintain its composition closest to the beginning.

\subsection{Physical and physiological seeds characterization}

The physical characterization of the seeds was made through gas pycnometry techniques to determine the actual density, test cylinder to determine the bulk density, pachymetry to determine the mean diameter and the sphericity. The porosity was determined by the ratio of the actual specific mass and bulk specific mass.

For physiological characterization, germination tests were performed following the methodology recommended by the Rules for Testing Seeds (Brasil, 1992). This analysis consisted in the use of seedling boxes with filter paper, where 100 seeds were placed. The germination tests were made in a germinating greenhouse operating at a temperature of $20^{\circ} \mathrm{C}$ and maintaining the photoperiod. These procedures were made in quadruplicate. The counting rates of germination proceeded in the fifth and fourteenth days after the start of the test.

\subsection{Rewetting of the seeds}

Due to the difficulty of obtaining seeds at harvest time, ideal situation for the drying process, the seeds were acquired ready for planting, which means, dried until the commercial moisture content. Due to this, it was necessary to carry out the process of rewetting of the seeds. 
The process of rewetting was performed according to the saturation methodology proposed by Arnost Jr. (1997). This consisted of exposing the seeds indoors and saturated at a temperature of $35^{\circ} \mathrm{C}$. The equipment used to promote this saturated environment was a thermostatic bath.

A layer of about $2 \mathrm{~cm}$ arranged in a bottom bracket was used in the rewetting of the seeds to turn easier the mass transfer process. In the rewetting process each every twelve hours of processing, the moisture content of the seeds was evaluated by the gravimetric method recommended by the Association of Official Analytical Chemists - AOAC (1997). Another variable obtained after the rewetting process were the germinating indexes. These analyzes were performed following the methodology recommended by the Rules for Testing Seeds (Brasil, 1992).

In this study, the study of rewetting was performed in duplicate to ensure the data reproducibility.

\subsection{Desorption isotherms}

The desorption isotherms were determined following the gravimetric static method rules, using sulfuric acid solutions in eleven different concentrations ensured that the variation of relative humidity remained in a range of 5-89\%. The experiments were conducted at temperatures of 40 and $60^{\circ} \mathrm{C}$. Each assay was performed in triplicate, using sealed glass containers and a plastic crucible.

Inside of each container, $30 \mathrm{~mL}$ of sulfuric acid solution were added. It was also placed in each plastic crucible approximately $1 \mathrm{~g}$ of rewetted ryegrass seeds using the previously seen methodology. The sealed glass containers were placed in forced-circulation oven at temperatures of 40 and $60^{\circ} \mathrm{C}$. The crucible weighing was performed on the first, seventh, tenth and fourteenth day of the experiment. These weighing were made with the objective of verifying the mass balance for each studied atmosphere. With the thermal equilibrium achieved on the fourteenth day, the moisture content of the seeds was determined by the gravimetric method recommended by the Association of Official Analytical Chemists - AOAC (1997).

The results obtained in the isotherms were analyzed by fitting the experimental data to the models of BET, GAB, Oswin, Peleg and Hederson.

\subsection{Drying process}

The Figure 1 shows an illustrative photograph of the fixed bed with parallel air flow drier utilized on this study.

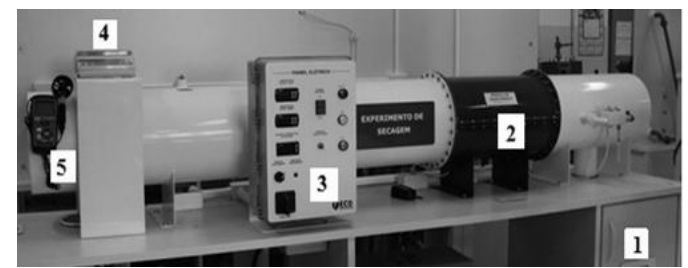

Figure 1 - Fixed bed dryer with parallel air flow. (1) Centrifugal Blower, (2) Heat Exchanger, (3) Control Panel, (4) Digital Scale and (5) Vane Anemometer. 
The variables studied in the drying process were the drying air temperature of 40 and $60{ }^{\circ} \mathrm{C}$, the air velocity at levels of 1.0 and $2.0 \mathrm{~m} / \mathrm{s}$ and the height dimensions of the tray 0.005 and $0.01 \mathrm{~m}$. In those dryings the solids loading in the tray varied between 6 and $12 \mathrm{~g}$, according to the height of the tray used.

For each studied condition, the system was monitored for each 5 minutes during the first 30 minutes of drying and each 10 minutes until the system reaches the mass balance. The variables measured during the experiments were the temperatures of dry and wet bulb of the inlet air, the temperature of the drying air and the mass into the tray.

With the temperature values of dry bulb and wet bulb at the entrance of the dryer and the value of the drying air temperature, the relative and absolute humidity was determined before and after heating the drying air. This determination was made by the Free Software Catt2 (available on: www.catt.se), which is specific for psychrometric calculations. For each experiment, the moisture content of the samples, both before and after the drying process were obtained by the gravimetric method recommended by the Association of Official Analytical Chemists - AOAC (1997). Were also determined for each experiment the germination rates of the final product using the methodology recommended by the Rules for Testing Seeds (Brasil, 1992).

\section{Results and discussions}

The Table 1 presents the results on physical and physiological characterization of commercial seed purchased in the local market.

Table 1 - Results of physical and physiological characterization of commercial seed purchased in the local market.

\begin{tabular}{cc}
\hline Property & Value \\
\hline$U_{B U}(\%)$ & $12,56 \pm 0,01$ \\
$d_{p}(\mathrm{~mm})$ & $0,625 \pm 0,29$ \\
$\rho_{r}\left(\mathrm{~kg} / \mathrm{m}^{3}\right)$ & $1366 \pm 4,60$ \\
$\rho_{b}\left(\mathrm{~kg} / \mathrm{m}^{3}\right)$ & $280 \pm 2,83$ \\
$\varepsilon$ & $0,80 \pm 0,01$ \\
$\phi$ & $0,17 \pm 0,01$ \\
$I_{G}(\%)$ & $61,00 \pm 4,5$ \\
\hline
\end{tabular}

By the analyses of the Table 1, the moisture content of seeds bought in the local market is verified that its value is in the ideal range, according to Macedo et al., (1987), for the marketing of ryegrass seeds (range 12 to $15 \%$ ). The results obtained for $\rho_{r}, \rho_{b}, \varepsilon, \phi$ and $d_{p}$ were not compared with the literature due to lack of data of this type found in the bibliographies. The germination index showed a satisfactory value required for commercial standards (SEAPA - Secretaria da Agricultura do Estado).

In the Figure 2, the study of the rewetting of ryegrass seeds purchased in the local market process is presented. 


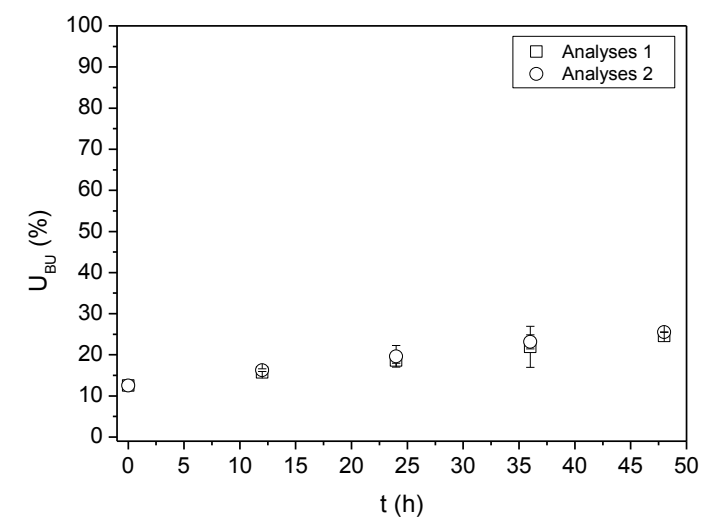

Figure 2 - Moisture Wet versus time basis.

It is observed in Figure 2 that the rewetting process was efficient, as it enabled raise the moisture content of the seeds of approximately $12 \%$ on a wet basis (Table 1) to values of approximately $25 \%$ on a wet basis. When analyzing these results it is found that these values are very close to those found in freshly harvested seeds that went through the cleaning process (Maia, 1995).

Another important aspect to note is that a rewetting process is also an aging treatment of seeds. Therefore, it is necessary that the process of rewetting will not be applied for long periods due to the combined effect of time-temperature-moisture can reduce seed germination by aging. In the case of this study, the rewetting times greater than $48 \mathrm{~h}$ caused the attack of fungi and microorganisms that have prevented the use of samples.

About the rate of germination, it was observed that the seeds that have been rewetted for 48 h showed a value of $66.0 \pm 4.7 \%$. By comparing this value with that obtained for commercial seed purchased in the local market (Table 1), it is found that both are very close. Because of this, it is possible to say that the process of rewetting did not cause any physiological damage to the seeds. Therefore, all the rewetting processes carried out on the seeds for studies of drying and desorption isotherms, were made at $35^{\circ} \mathrm{C}$ and time of 48 hours.

The Table 2 shows the values of the parameters calculated from the fit of the isotherm model GAB, BET, Oswin, Peleg and Henderson. Also in this table the respective coefficients of determination $\left(R^{2}\right)$ for each fitted to the experimental data model is presented.

Analyzing the Table 2, for the coefficient of determination, is it possible to affirm that the Oswin model was the best in describing the isotherms of temperatures studied in ryegrass. This may have occurred because its model is based on mathematical expansion sigmoidal shaped curve, providing advantages over kinetic models of BET and GAB, having only two linearization constants. The tuning parameters for the Oswin model found in this study are in agreement with the literature. Blahovec (2004) indicates values of $a>0$ and values $1 \geq b>0$.

Table 2 - Values of the parameters calculated from the fit of models GAB, BET, Oswin, Peleg and Henderson.

\begin{tabular}{cccc}
\hline Model & Parameter & Value at $40^{\circ} \mathrm{C}$ & $R^{2}$ \\
\hline \multirow{2}{*}{ BET } & $X_{m}$ & 0,05831 & 0,981
\end{tabular}




\begin{tabular}{|c|c|c|c|}
\hline & $n$ & 47,1424 & \multirow{4}{*}{0,993} \\
\hline \multirow{3}{*}{ GAB } & $X_{m}$ & 0,0713 & \\
\hline & $C$ & 67,859 & \\
\hline & $k$ & 0,7635 & \\
\hline \multirow{3}{*}{ Oswin } & $a$ & 0,1173 & \multirow{3}{*}{0,993} \\
\hline & $b$ & 0,3046 & \\
\hline & $k_{1}$ & 0,2937 & \\
\hline \multirow{3}{*}{ Peleg } & $n_{1}$ & 0,1255 & \multirow{3}{*}{0,991} \\
\hline & $k_{2}$ & 3,8879 & \\
\hline & $n_{2}$ & 0,1538 & \\
\hline \multirow{2}{*}{ Hederson } & $a$ & 76,2847 & \multirow{2}{*}{0,964} \\
\hline & $b$ & 2,24654 & \\
\hline Model & Parameter & Value at $60^{\circ} \mathrm{C}$ & $R^{2}$ \\
\hline \multirow{4}{*}{ BET } & $X_{m}$ & 0,04381 & \multirow{3}{*}{0,971} \\
\hline & $C$ & 59,2552 & \\
\hline & $n$ & 8,51261 & \\
\hline & $X_{m}$ & 0,05498 & \multirow{3}{*}{0,993} \\
\hline \multirow{2}{*}{ GAB } & $C$ & 27,4597 & \\
\hline & $k$ & 0,7954 & \\
\hline \multirow{3}{*}{ Oswin } & $a$ & 0,08866 & \multirow{2}{*}{0,997} \\
\hline & $b$ & 0,35761 & \\
\hline & $k_{1}$ & 0,1257 & \multirow{4}{*}{0,993} \\
\hline \multirow{3}{*}{ Peleg } & $n_{1}$ & 0,5050 & \\
\hline & $k_{2}$ & 0,1744 & \\
\hline & $n_{2}$ & 7,6803 & \\
\hline \multirow{2}{*}{ Hederson } & $a$ & 52,4121 & \multirow{2}{*}{0,975} \\
\hline & $b$ & 1,82443 & \\
\hline
\end{tabular}

Based on the coefficient of determination, the model that was used to fit the desorption isotherms of the rewetted ryegrass seed was Oswin. The experimental curves adjusted by this model are shown in the Figure 3.

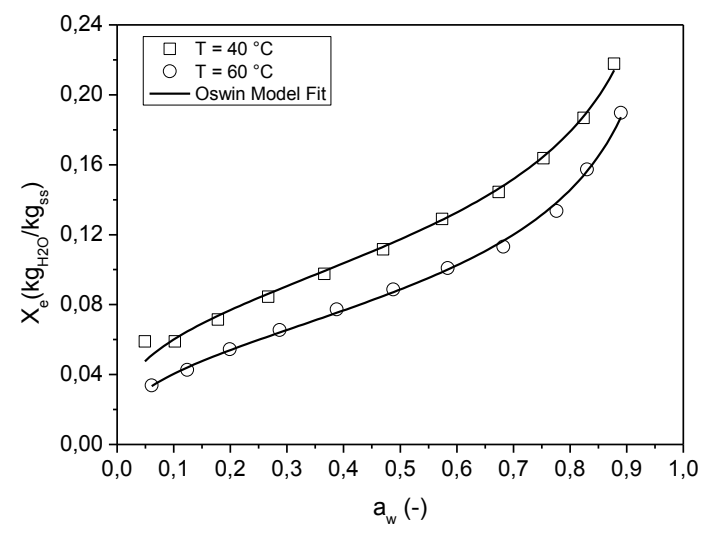

Figure 3 - Ryegrass isotherms at temperatures of 40 and $60^{\circ} \mathrm{C}$ adjusted to Oswin model.

Observing from the ryegrass isotherm on the Figure 3, it is possible to realize that this curve is classified as the type II, following the classification of Brunauer, 1938. The sigmoidal shape of the classification of the type II isotherm is characteristic of organic products. This type of isotherm results from some adsorbents in which there is a wide range of pore sizes. This variation allows the capacity of the adsorbent move continuously from a monolayer to a multilayer adsorption followed by capillary condensation. 
In the Figure 4, it is shown the curves of water free dimensionless versus time for all dryings that have been made in this study.

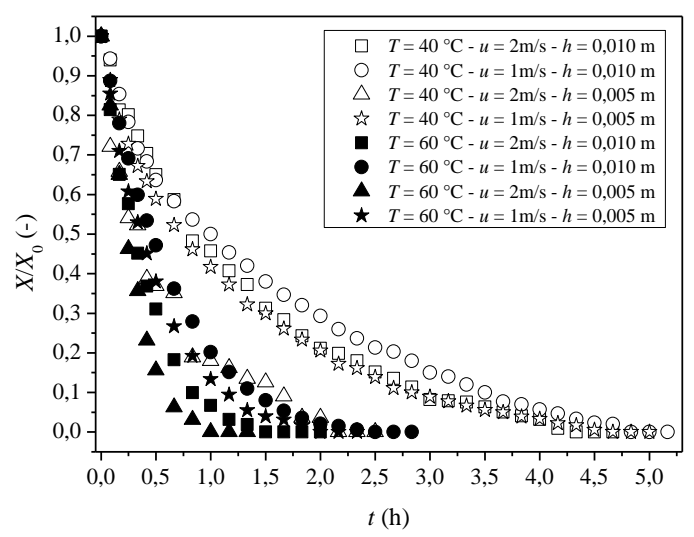

Figure 4 - Water free dimensionless versus time.

It is noted that in the Figure 4 all the curves exhibited a characteristic drying behavior, with a decrement free water content $\mathrm{s}$ as a function of time. In this figure, when analyzing the influence of temperature and velocity of the drying air is observed that the increase of these variables promoted a reduction of drying time. The increase of the height of the tray promoted an increase in drying time. This result is consistent with the physically expected. The increase of temperature and air velocity causes an increase of the driving force of the drying process, thereby facilitating the transfer of heat and mass of the system. On the other hand, the increase in height of the tray causes a larger resistance to the drying process, which makes the heat and mass transfer harder.

The Table 3 shows the results of the final moisture contents and total dry seeds for germination in accordance with the experimental conditions in this research.

Table 3 - Final humidity and total germinations indexes of the dry seeds.

\begin{tabular}{ccc}
\hline$T=40^{\circ} \mathrm{C}$ & $U_{B U}(\%)$ & $I_{G}(\%)$ \\
$u=2 \mathrm{~m} / \mathrm{s}$ & $9,65 \pm 0,07$ & $62,8 \pm 4,4$ \\
$h=0,010 \mathrm{~m}$ & & \\
$T=40^{\circ} \mathrm{C}$ & $10,21 \pm 0,12$ & $72,0 \pm 6,8$ \\
$u=1 \mathrm{~m} / \mathrm{s}$ & & \\
$h=0,010 \mathrm{~m}$ & $11,46 \pm 0,62$ & $66,5 \pm 1,3$ \\
$T=40^{\circ} \mathrm{C}$ & & \\
$u=2 \mathrm{~m} / \mathrm{s}$ & & \\
$h=0,005 \mathrm{~m}$ & $8,71 \pm 0,11$ & \\
$T=40^{\circ} \mathrm{C}$ & & \\
$u=1 \mathrm{~m} / \mathrm{s}$ & & \\
$h=0,005 \mathrm{~m}$ & $6,27 \pm 0,05$ & \\
$T=60{ }^{\circ} \mathrm{C}$ & & \\
$u=2 \mathrm{~m} / \mathrm{s}$ & & \\
$h=0,010 \mathrm{~m}$ & & \\
$T=60{ }^{\circ} \mathrm{C}$ & $6,21 \pm 0,03 \pm 3,3$ \\
$u=1 \mathrm{~m} / \mathrm{s}$ & & $59,0 \pm 7,9$ \\
$h=0,010 \mathrm{~m}$ & $6,71 \pm 0,13$ & \\
$T=60{ }^{\circ} \mathrm{C}$ & & \\
$u=2 \mathrm{~m} / \mathrm{s}$ & & \\
$h=0,005 \mathrm{~m}$ & & \\
\hline
\end{tabular}




$$
\begin{array}{cc}
T=60^{\circ} \mathrm{C} & \\
u=1 \mathrm{~m} / \mathrm{s} & 6,02 \pm 0,03 \\
h=0,005 \mathrm{~m} & 65,5 \pm 3,0
\end{array}
$$

Analyzing the results in the Table 3, it was verified that the results obtained for moisture on a wet basis of dry seeds were between 9 and $11 \%$ for the drying performed at $40^{\circ} \mathrm{C}$ and approximately $6 \%$ in the drying performed at $60^{\circ} \mathrm{C}$. This result is in agreement with the expected physically. Since the temperature rise promotes a reduction in relative humidity of the environment, it is expected that the removal of moisture is more effective at higher temperatures.

Regarding to germination rates, is shown in Table 3 that almost all values are very close to those found in commercial seeds acquired in the local market (Table 1), except for the condition of $60{ }^{\circ} \mathrm{C}$, speed air $2 \mathrm{~m} / \mathrm{s}$ and $0.010 \mathrm{~m}$ height of the tray. This fact indicates that these drying did not modify the physiological qualities of the seeds. Another important aspect observed in this table that the drying was carried out at $40^{\circ} \mathrm{C}$ had germination rates tending towards to higher values than those found in drying at $60^{\circ} \mathrm{C}$. This fact may indicate the influence of drying temperature on seed quality. Despite of this trend, further studies are still required to get more accurate conclusions about this variable.

\section{Conclusions}

In physical characterization of commercial seeds it was possible to get a value of the average diameter of $0.625 \pm 0.29 \mathrm{~mm}$, specific mass of $1366 \pm 4.60 \mathrm{~kg} / \mathrm{m}^{3}$, the bulk specific mass of $280 \pm$ $2.83 \mathrm{~kg} / \mathrm{m}^{3}$, porosity of $0.80 \pm 0.01$, sphericity of $0.17 \pm 0.01$, moisture content of $12.56 \pm 0.01 \%$ and the germination rate of $61.00 \pm 4,50 \%$.

By the study of the rewetting process it can be concluded that it was appropriate for the ryegrass seeds (Lolium multiflorum L.), since that this process did not damage the seeds and put them in possible moisture levels close to those found in freshly harvested seeds that have been passed through the cleaning process.

In the study of the desorption isotherms, it can be concluded that the shape of the isotherm of the ryegrass seeds (Lolium multiflorum L.) is the Type II following the classification of BRUNAUER, 1938. Also it can be concluded in this study, the mathematical model that best represented the isotherms at temperatures of 40 and $60^{\circ} \mathrm{C}$ was Oswin with a coefficient of determination greater than 0.993 .

For the study of the drying of rewetted seeds it can be concluded that all experimental conditions studied in this work made it possible to put the final seed moisture contents of under the required commercially conditions. In the analysis of free water dimensionless as a function of time is concluded that an increase in the height of the tray gave a decrease in the drying process. It is also possible to conclude from these dimensionless, that the temperature influences the speed of the air in the drying process by increasing the driving force of the process. 
Finally, it is concluded that for the drying conditions studied, the physiological tests of dry seeds showed germination rates very close to those found in commercial seeds purchased in the local market. This fact shows the process conditions investigated in this study did not cause significant physiological damage to the seeds.

\section{Nomenclature}

\begin{tabular}{|c|c|c|}
\hline Symbol & Notation & Unit \\
\hline$a$ & Model Constant & {$[-]$} \\
\hline$a_{w}$ & Water activity & {$[-]$} \\
\hline$b$ & Model Constant & {$[-]$} \\
\hline$C$ & Model Constant & {$[-]$} \\
\hline$d_{p}$ & Particle diameter & [L] \\
\hline$I_{G}$ & Germination índex & {$[-]$} \\
\hline$k$ & Model Constant & {$[-]$} \\
\hline$k_{1}$ & Model Constant & {$[-]$} \\
\hline$k_{2}$ & Model constant & {$[-]$} \\
\hline$n$ & Model constant & {$[-]$} \\
\hline$n_{1}$ & Model constant & {$[-]$} \\
\hline$n_{2}$ & Model constant & {$[-]$} \\
\hline$t$ & Time & {$[\mathrm{T}]$} \\
\hline$U_{B U}$ & Wet basis humidity & {$[-]$} \\
\hline$X / X_{0}$ & $\begin{array}{l}\text { Free water } \\
\text { dimensionless }\end{array}$ & {$[-]$} \\
\hline$x_{e}$ & Moisture equilibrium & {$\left[\mathrm{MM}^{-1}\right]$} \\
\hline$X_{m}$ & $\begin{array}{l}\text { Humidity of the } \\
\text { monolayer material }\end{array}$ & {$\left[\mathrm{MM}^{-1}\right]$} \\
\hline$\varepsilon$ & Porosity & {$[-]$} \\
\hline$\rho_{b}$ & Bulk specific mass & {$\left[\mathrm{ML}^{-3}\right]$} \\
\hline$\rho_{r}$ & Real specific mass & {$\left[\mathrm{ML}^{-3}\right]$} \\
\hline$\phi$ & Sphericity & {$[-]$} \\
\hline
\end{tabular}

\section{Aknowledgements}

The authors of this study thank the UNIPAMPA/Bagé and EMBRAPA/Pecuária Sul for the available infrastructure and the $\mathrm{CNPq}$ and CAPES for granting scholarships.

\section{References}

ANDRADE, E. T. 2003. Qualidade até o final: Secagem certa. Cultivar Máquinas. 3(25): 15. In: Andrade, E. T., Correa, P. C., Teixeira, L. P., Pereira, R. G. and Caloment, J. F. 2006. Cinética de Secagem e Qualidade de Sementes de Feijão. Engevista, 8(2): 83-95.

A.O.A.C. 1997. Association of Oficial Analytical Chemists. (16th ed) Official methods of analysis.Washington D. C.

Arnosti Jr., S. 1997. Desenvolvimento de um Secador Transportador do Tipo Esteira com Escoamentos Cruzados e Caracterização de Sementes de Gramíneas. Programa de PósGraduação em Engenharia Química (Doutorado): 232.

Atefi, M., Taslimi, A., Hassas, M. R. and Mazlumi, M. T. 2004. Effect of Freezedrying Processe on the Qualitative Charactristics of Iranian Saffron. Journal of Food Science. 
Technology, 1(2): 41-49. In: Mortezapour, H., Ghobadian, B., Khoshtaghaza, M. H. and Minaei, S. 2014. Drying Kinetics and Quality Characteristics of Saffron Dried with a Heat Pump Assisted Hybrid Photovoltaic-thermal Solar Dryer. Journal of Agricultural Science and Technology,16: 33-45.

Blahovec, J. 2004. Sorption isotherms in materials of biological origin mathematical and physical approach. Journal of Food Engineering, 65: 489-495.

Brasil, M. A. R. A. 1992. Regras para Análise de Sementes. Brasília: 365.

Celma, A. R., López-Rodriguéz, F. and Blázquez, C. 2009. Experimental modelling of infrared drying of industrial grape by-products. Food and Bioproducts Processing, 87: 247253. In: Ferreira, L. F. D., Pirozi, M. R., Ramos, A. F., and Pereira, J. A. M. 2012. Mathematical modeling of thin-layer drying of fermented grape pomace. Pesquisa Agropecuária Brasileira, 47(6): 855-862.

Chen, C. and Jayas, D.S. 1998. Evaluation of the GAB equation for the isotherms of agricultural products. Transactions of ASAE, 41(6): 1755-1760.

Corrêa, P. C., Ribeiro, D. M., Resende, O. and Botelho, F. M. 2006. Determinação e modelagem das propriedades físicas e da contração volumétrica do trigo, durante a secagem. Revista Brasileira de Engenharia Agrícola e Ambiental, 10(3): 665-670. In: Menezes, M. L., Ströher, A. P., Pereira, N. C. and Barros, S. T. D. 2013. Análise da cinética e ajustes de modelos matemáticos aos dados de secagem do bagaço de maracujá-amarelo. Engevista, 15(2): 176-186.

De Oliveira, O. L. P. and Barreto, I. L. 1976. Efeito de calcário e método de semeadura no comportamento de espécies forrageiras temperadas no melhoramento de pastagem natural. Pesquisa Agropecuária Brasileira, 11: 49-56.

Faria, L. J. G. and Rocha, S. C. S. 2000. Optimization of Annatto (Bixa orellana L.) Drying in Fixed Bed, Brazilian Journal of Chemical Engineering, 17: 4-7.

Ferrari Filho, E. 2011. Métodos e temperaturas de secagem sobre a qualidade físico-química e microbiológica de grãos de milho no armazenamento. Universidade federal do Rio Grande do Sul, Programa de Pós-graduação em Fitotecnia (Mestrado):5.

Figueirêdo, R. M. F. and Queiroz, A. J. M. 2007. Isotermas se adsorção de umidade da pitanga em pó. Revista de Biologia e Ciências da Terra, 7(1).

Gomes, P. M. A., Figueirêdo, R. M. F. and Queiroz, A. J. M. 2002. Caracterização e isotermas de adsorção de umidade da polpa de acerola em pó. Revista Brasileira de Produtos Agroindustriais, 4(2): 157-165.

Goneli, A. L. D. 2008. Variação das propriedades físico-mecânicas e da qualidade da mamona (Ricinus communis L.) durante a secagem e o armazenamento. Universidade Federal de Viçosa (Doutorado): 198-199.

Haghi, A. K. and Amanifard, N. 2008. Analysis of heat and mass transfer during microwave drying of food products. Brazilian Journial of Chemical Engineering, 25: 491-501.

Keey, R. B. 1992. Drying of Loose and Particulate Materials, New York: Hemisphere Publ.: 29-32. In: Ambrosio, M. C. B. and Taranto, O. P. 2002. The drying of solids in a modified fluidized bed. Brazilian Journal of Chemical Engineering, 19(3): 355-358.

Macedo, G. A. R., Marques Neto, J. E. and Batista, J. S. 1987. Secagem à sombra e ao sol de sementes de gramíneas forrageiras. Revista Brasileira de Sementes, 9(3): 29-37.

Maia, M. S. 1995. Secagem de sementes de azevém anual (Lolium multiflorum) com ar ambiente forçado. Universidade Federal de Pelotas (Doutorado): 107-108.

Martinazzo, A. P., Corrêa, P. C., Resende, O. and Melo, E. C. 2007. Análise e descrição matemática da cinética de secagem de folhas de capim-limão. Revista Brasileira de Engenharia Agrícola e Ambiental, 11(3): 301-306. In: Fiorentin, L. D., Menon, B. T., Alves, J. A., De Barros, S. T. D., Pereira, N. C., Lima, O. C. M. and Modenes, A. N. 2012. Análise da Secagem do Bagaço de Laranja em Camada Fina Utilizando Modelos Semi-teóricos e Empíricos. Engevista, 14(1): 22-33. 
Morey, V. W. F., Meronuck, R. A. and Lang, J. P. 1995. Relationship between equilibrium relative humidity and deterioration of shelled corn. Transactions of ASAE, 38(4): 1139-1145. Mota, F. S., Berny, Z. B. and Mota, J. F. A. S. 1981. Índice climático de crescimento de pastagens naturais no Rio Grande do Sul. Pesquisa Agropecuária Brasileira, 16(4): 453472.

Mujumdar, A. S., 1987. Handbook of Industrial Drying. New York: Marcel Dekker. In: Tulek, Y. 2011. Drying Kinetics of Oyster Mushroom (Pleurotus ostreatus) in a Convective Hot Air Dryer. Journal of Agricultural Science and Technology, 13: 655-664.

Park, K. J., Nogueira, R. I. 1992. Modelos de ajuste de isotermas de sorção de alimentos. Engenharia Rural, 3(1): 81-86.

Samaniego-Esguerra, C. M., Boag, I. F. and Robertson, G. L. 1991. Comparison of regression methods for fitting the Gab model to the moisture isotherms of some dried fruit and vegetables. Journal of Food Engineering, 13(2): 115-133.

Samapundo, S., Devlieghere, F., Meulenaer, B., Atukwase, A., Lamboni, Y. and Debevere, J. M. 2007. Sorption isotherms and isosteric heats of sorption of whole yellow dent corn. Journal of Food Engineering, 79: 166-168. In: Oliveira, E. G., Rosa, G. S., Moraes, M. A. and Pinto, L. A. A. 2009. Moisture sorption characteristics of microalgae Spirulina platensis, Brazilian Journal of Chemical Engineering, 26(1): 189-197.

Singh, G. D., Sharma, R., Bawa, A. S. and Saxena, D. C. 2008. Drying and Rehydration Characteristics of Water Chestnut (Trapa natans) as a Function of Drying Air Temperature. Journal of Food Engineering, 87: 213-221. In: Lee, J. H., Kim, H. J. and Rhim, J. W. 2012. Vacuum Drying Characteristics of Salicornia herbacea L. Journal of Agricultural Science and Technology,14(1): 587-598.

Strumillo, C. Z. and Kudra, T. Drying: principles, applications and design. In: Hughes, R. 1986. Topics in chemical engineering. UK: Gordon and Breach Science Publisher, 3. 